\title{
IMPLEMENTASI PENGGUNAAN DANA DESA TERHADAP PEMBANGUNAN (STUDI KASUS DESA SENGKUBANG KECAMATAN MEMPAWAH HILIR PROVINSI KALIMATAN BARAT)
}

\author{
Meika Rozandi ${ }^{*}$, Kumba Digdowiseiso ${ }^{1}$ \\ ${ }^{1}$ Program Studi Administrasi Publik, Universitas Nasional Jakarta \\ Email: meikarozandixxiii@yahoo.co.id, kumba.digdo@civitas.unas.ac.id \\ *Korespondensi penulis: meikarozandixxiii@yahoo.co.id \\ (Submission 26-01-2021, Revission 27-04-2021, Accepted 04-06-2021)
}

\begin{abstract}
This study aims to analyze the implementation of Sengkubang Village Fund in the development of Sengkubang Village. Village Fund has an important role in helping the local government. The regional government as an autonomous region has the authority to carry out the management, administration, and development of the government. This research is a descriptive qualitative research method in the form of a case study used to examine the conditions of the implementation of Sengkubang Village Fund in the development of Sengkubang Village. Sengkubang Village Fund in 2018 received a Village Fund allocation of Rp791.405.000,00 and in 2019 it received a Village Fund allocation of Rp1.056.613.000,00. Builders in Sengkubang village based on the Indonesian Village Data Center showed that in 2018 the value of Village Development Index was 0.623, and in 2019, the value of the Village Development Index was 0.823. In 2020, Sengkubang Village Development Index experienced an increase by $6.93 \%$ and was recorded as a classification of independent villages.
\end{abstract}

Keywords: village fund, autonomy, allocation, village development index, implementasi

\begin{abstract}
Abstrak
Penelitian ini bertujuan untuk menganalisis pelaksanaan dana Desa Sengkubang dalam pembangunan Desa Sengkubang. Dana desa mempunyai peran penting dalam membantu pemerintah daerah. Pemerintah daerah sebagai daerah otonomi mempunyai wewenang dalam pelaksanaan pengelolaan, penyelenggaraan dan pembangunan pemerintah. Penelitian ini adalah penelitian metode kualitatif deskriptif berupa studi kasus yang digunakan untuk meneliti pada kondisi pelaksanaan dana Desa Sengkubang dalam pembangunan Desa Sengkubang. Dana Desa Sengkubang pada tahun 2018 mendapatkan alokasi dana desa sebesar Rp791.405.000,00 dan pada tahun 2019 mendapatkan alokasi dana desa sebesar Rp.1.056.613.000,00. Pembangun pada Desa Sengkubang bedasarkan Pusat Data Desa Indonesia menunjukan pada tahun 2018 nilai Indeks Desa Membangun (IDM) sebesar 0.623 dan pada tahun 2019 nilai IDM sebesar 0.823 dan Pada tahun 2020 IDM Desa Sengkubang mengalami kenaikan nilai IDM sebanyak $6,93 \%$ dan tercatat sebagai klasifikasi desa mandiri.
\end{abstract}


Kata kunci: dana desa, otonomi, alokasi, nilai indeks desa membangun, implementasi

\section{PENDAHULUAN}

Pemerintah desa melalui dana desa mempunyai peran penting dalam membantu pemerintah daerah. Pemerintah daerah sebagai daerah otonomi mempunyai wewenang dalam pelaksanaan pengelolaan, penyelenggaraan dan pembangunan pemerintah. Dana desa diharapkan dapat memberikan bantuan yang berdampak pada perkembangan desa. Dana desa sesuai dengan rencana kerja pemerintah desa diharapkan memberikan manfaat untuk dapat membiayai pembangunan dan pemberdayaan yang bertujuan meningkatkan kesejahteraan masyarakat desa, penanggulangan kemiskinan dan peningkatan kualitas hidup manusia.

Desa Sengkubang adalah salah satu desa yang berada di Kecamatan Mempawah Hilir, Kabupaten Mempawah Provinsi Kalimantan Barat yang mendapatkan dana desa. Desa Sengkubang terletak di luar kawasan hutan dan berbatasan dengan laut dan memiliki 846 keluarga (Badan Pusat Statistik, 2016). Dana desa yang diberikan bertujuan meningkatkan pemerintahan yang good governance. Good governance adalah tata kelola pemerintahan yang baik dan sesuai dengan peraturan yang sudah ada. Good governance memiliki sembilan prinsip yaitu salah satuya efektivitas dan efesien.

Bedasarkan latar belakang diatas, maka rumusan masalah pada penelitian ini sebagai berikut:

1. Bagaimana Implementasi Dana Desa pada Desa Sengkubang Kecamatan Mempawah Hilir?

2. Bagaimana Pembangunan dari Dana Desa pada Desa Sengkubang Kecamatan Mempawah Hilir?

Dana desa menurut (Peraturan Menteri Desa, Pembangunan Daerah Tertinggal, dan Transmigrasi Republik Indonesia Nomor 6 Tahun 2020 tentang Perubahan Atas Peraturan Menteri Desa, Pembangunan Daerah Tertinggal; dan Transmigrasi Nomor 11 Tahun 2019 Tentang Prioritas Penggunaan Dana Desa Tahun 2020) adalah dana yang bersumber dari Anggaran Pendapatan dan Belanja Negara (APBN) yang diperuntukkan bagi desa yang ditransfer melalui Anggaran Pendapatan dan Belanja Daerah kabupaten dan digunakan untuk mendanai penyelenggaraan, pembinaan kemasyarakatan, dan pemberdayaan masyarakat. Adapun tujuan pemerintah menyalurkan dana desa adalah agar desa dapat mengatur dan mengelola pembangunan dan pemberdayaan masyarakat desa. Dana desa tersebut dikelola melalui mekanisme pembangunan masyarakat desa dan terencana terkait pembangunan desa yang dibahas dan disepakati dalam musyawarah desa.

Implementasi menurut Kamus Besar Bahasa Indonesia (KBBI) menyebutkan bahwa pelaksanaan atau penerapan dan istilah ini berkaitan dengan suatu pelaksanaan kegiatan dalam mencapai suatu tujuan. Sedangkan menurut (Edwards, 1980) implementasi kebijakan adalah adalah suatu proses yang bersifat krusial karena seberapa baiknya suatu kebijakan kalau tidak direncanakan dan dipersiapkan dengan baik implementasinya maka tujuan dari kebijakan publik tidak 
akan tercapai. Edwards dalam (Indiahono, 2009) menyebutkan bahwa implementasi kebijakan dipengaruhi 4 (empat) indikator yang saling berhubungan satu sama lain, diantaranya:

1) Komunikasi merupakan keberhasilan implementasi kebijakan mensyaratkan agar implementator mengetahui apa yang harus dilakukan, dimana yang menjadi tujuan dan sasaran kebijakan harus ditransmisikan kepada kelompok sasaran (target group), sehingga akan mengurangi distrosi implementasi.

2) Sumber daya dapat membantu implementor dalam melaksanakan kebijakan secara efektif. Sumber daya tersebut dapat berupa sumber daya manusia, misalnya kopetensi implementor dan sumber daya finansial.

3) Disposisi merupakan karakteristik dan watak yang ada dalam implementor. Jika implementor mempunyai diposisi yang baik maka kebijakan tersebut dapat berjalan dengan baik sesuai dengan tujuan dari kebijakan.

4) Struktur Birokrasi adalah susunan komponen (unit-unit) kerja dalam suatu organisasi yang adanya pembagian kerja dan fungsi dari kegiatan - kegiatan yang berbeda-beda diintegrasikan atau dikoordinasikan. Struktur birokrasi menunjukan spesialisasi pekerjaan, saluran perintah dan penyampaian laporan.

Menurut (Siagian, 2010), pembangunan adalah suatu rangkaian usaha mewujudkan pertumbuhan dan perubahan secara terencana dan sadar yang ditempuh oleh suatu negara bangsa menuju modernitas dalam rangka pembinaan bangsa. Sedangkan menurut Tjokroamidjojo dalam (Listyaningsih, 2014), istilah pembangunan belum menemukan suatu kesepakatan arti seperti halnya modernisasi. Listyaningsih (2014) menjelaskan bahwa pembangunan didefinisikan sebagai rangkaian usaha mewujudkan pertumbuhan secara terencana dan sadar yang ditempuh oleh suatu negara menuju arah yang lebih baik. Dari teori-teori diatas, dapat didefinisikan bahwa pembangunan adalah rangkaian usaha mewujudkan pertumbuhan dan perubahan secara terencana dan sadar yang ditempuh oleh suatu negara dan bangsa menuju modernitas. Selain itu, pembangunan juga diarahkan kepada perubahan paradigma atau mindset masyarakat dari tradisional menuju modern. Maka, dapat ditarik kesimpulan bahwa pembangunan adalah sebuah proses yang harus dilalui sebuah negara dalam rangka pencapaian tujuan negara bersangkutan.

Sebagaimana diatur dalam (Undang-Undang Republik Indonesia Nomor 6 Tahun 2014 tentang Desa Bab IX) tentang pembangunan kawasan pedesaan dijelaskan bahwa pembangunan desa-desa adalah upaya peningkatan kualitas hidup dan kehidupan untuk sebesar-besarnya kesejahteraan masyarakat desa. Pembangunan desa bertujuan untuk meningkatkan kesejahteraan masyarakat desa dan kualitas hidup manusia serta penanggulangan kemiskinan melalui pemenuhan kebutuhan dasar, pengembangan potensi ekonomi lokal, serta pemanfaatan sumber daya alam dan lingkungan secara berkelanjutan. Pembangunan desa mempunyai tahapan- tahapan yang harus dilakukan yaitu:

1) Tahapan perencanaan, dimana perencanaan pembangunan desa harus mengacu pada perencanaan pembangunan kabupaten kota yang disusun 
secara berjangka meliputi rencana pembangunan jangka menegah desa untuk waktu enam tahun dan rencana pembangunan tahunan desa yang disebut dengan rencana kerja pemerintah desa yang merupakan penjabaran dari rencana pembangunan jangka menegah desa untuk waktu satu tahun.

2) Tahapan pelaksanaan, dimana seluruh kegiatan pembangunan desa dilaksanakan sesuai rencana kerja pemerintah desa serta melibatkan seluruh masyarakat dengan semangat gotong royong.

3) Tahapan pengawasan, yang mana mayarakat juga berhak melakukan pemantauan atas pelaksanaan pembangunan desa dan berpartisipasi dalam musyawarah desa karena dalam musyawarah desa pemerintah diwajibkan untuk memberikan informasi secara terbuka tanpa ditutupi atas pelaksanakan berlangsungnya proses pembangunan dan anggaran pendapatan dan belanja sehingga masyarakat dapat memberi tanggapan terkait laporan pelaksanaan pembangunan yang ada di desa.

Berkaitan dengan pembangunan desa menurut (Peraturan Pemerintahan nomor 60 Tahun 2014 tentang Dana Desa yang bersumber dari Anggaran Pendapatan dan Belanja Negara), dana desa adalah dana yang bersumber dari Anggaran Pendapatan dan Belanja Negara (APBN) yang diperuntukan bagi desa yang di transfer melalui Anggaran Pendapatan dan Belanja Daerah Kabupaten dan digunakan untuk membiayai penyelenggaraan pemerintahan, pelaksanaan pembangunan, pembinanaan kemasyarakatan, dan pemberdayaan masyarakat.

Pengalokasian dana desa ditentukan berdasarkan jumlah penduduk desa, angka kemiskinan desa, serta tingkat kesulitan geografis. Tingkat kesulitan geografis yang dimaksud meliputi ketersediaan pelayanan dasar, kondisi infrastruktur, transportasi serta komunikasi desa ke kabupaten. Dana desa yang telah dialokasikan disalurkan oleh pemerintah kepada kabupaten dengan pemindahbukuan dari Rekening Kas Umum Negara (RKUN) ke Rekening Kas Umum Daerah (RKUD). Dana yang ada di RKUD selanjutnya disalurkan kepada desa dengan pemindahbukuan ke rekening kas Desa. Penyaluran dana desa terdiri dari tiga tahapan dengan rincian tahap pertama pada bulan April sebesar 40\%, tahap kedua pada bulan Agustus sebesar 40\% dan tahap ketiga pada bulan November sebesar $20 \%$.

Indeks Desa Membangun (IDM) merupakan indeks perhitungan gabungan yang didasari pada tiga indeks yakni Indeks Ketahanan Sosial (IKS), Indeks Ketahanan Ekonomi (IKE), serta Indeks Ketahanan Lingkungan (IKL). IDM dikembangkan dengan konsep perlu kerangka kerja pembangunan berkelanjutan di mana aspek sosial, ekonomi, dan ekologi saling mengisi, menjaga potensi kemampuan desa dan menjadi kekuatan untuk mensejahterakan kehidupan desa menuju desa maju dan mandiri. Kebijakan dan aktivitas pembangunan dan pemberdayaan masyarakat desa harus menghasilkan pemerataan dan keadilan, didasarkan dan memperkuat nilai-nilai lokal dan budaya, serta ramah lingkungan dengan mengelola potensi sumber daya alam secara baik dan berkelanjutan. Dalam konteks ini ketahanan sosial, ekonomi, dan ekologi bekerja sebagai dimensi yang memperkuat gerak proses dan pencapaian tujuan pembangunan dan pemberdayaan 
masyarakat desa. Angka IDM dihasilkan dari rata-rata dari ketiga indeks (IKS, IKE dan IKL) yang telah dihitung sebelumnya.

\section{METODE PENELITIAN}

Penelitian ini menggunakan metode campuran antara metode kuantitatif berupa data sekunder dan metode kualitatif berupa data primer yang dijelaskan dalam bentuk deskriptif. Data sekunder di peroleh dari Badan Pusat Statistika dan Kementerian Desa Pembangunan Daerah Tertinggal, dan Transmigrasi Republik Indonesia yang diunduh pada masing-masing portal instansi. Penelitian ini bertujuan untuk mengetahui analisis penggunaan dana desa dan perkembangan desa sesuai dengan IDM. Selanjutnya, penelitian ini menjelaskan implementasi penggunaan dana desa terhadap pembangunan di Desa Sengkubang Kecamatan Mempawah Hilir Provinsi Kalimantan Barat.

Menurut Kementerian Desa Pembanggunan Daerah Tertinggal dan Transmigrasi Republik Indonesia IDM dihitung menggunakan rumus sebagai berikut:

dimana

$$
I D M=\frac{I K S+I K E+I K L}{3}
$$
IDM : Indeks Desa Membangun
IKS : Indeks Ketahanan Sosial
IKE : Indeks Ketahanan Ekonomi
IKL : Indeks Ketahanan Lingkungan

Status desa berdasarkan IDM digolongkan menjadi lima klasifikasi yakni desa sangat tertinggal, tertinggal, berkembang, maju dan mandiri. Ambang batas skor IDM dari masing-masing klasifikasi tersebut sebagai berikut: 1) desa sangat tertinggal: kurang dari 0,$491 ; 2$ ) desa tertinggal: antara 0,491 s.d. 0,$599 ; 3$ ) desa berkembang: antara 0,599 s.d. 0,$707 ; 4$ ) desa maju: antara 0,707 s.d. 0,$815 ; 5)$ desa mandiri: lebih dari 0,815 (Taufik \& dkk, 2019).

Dalam proses perhitungan efektivitas dalam implementasi dana desa, penulis menggunakan rumus perhitungan sebagai berikut:

$$
\text { Efektivitas Dana Desa }=\frac{\text { Realisasi Dana Desa }}{\text { Pagu Dana Desa }} \times 100 \%
$$

Standar efektivitas menurut (Keputusan Menteri Dalam Negeri No. 690.900.327 tahun 2016 tentang Kriteria Penilaian dan Kinerja Keuangan) dapat diketahui efektif atau tidak dengan memenuhi kriteria sebagai berikut:
a. Diatas $100 \%$
: sangat efektif
b. Persentasi antara $90 \%$ s.d. $100 \%$ : efektif
c. Persentase antara $80 \%$ s.d. $90 \%$ : cukup efektif
d. Persentase antara $60 \%$ s.d. $80 \%$ : kurang efektif
e. Persentase dibawah $60 \%$ : tidak efektif. 


\section{HASIL DAN PEMBAHASAN}

\section{Alokasi Dana Desa Sekubang}

Dana desa adalah anggaran yang dialokasikan kepada desa yang ditransfer dari Anggaran Pendapatan dan Belanja Daerah (APBD) Kabupaten maupun kota yang diperuntukan untuk membiayai penyelenggaraan pemerintahan, pelaksanaan pembangunan, pembinaan kemasyarakatan, dan pemberdayaan masyarakat yang disebutkan dalam (Peraturan Menteri Desa, Pembangunan Daerah Tertinggal, dan Transmigrasi Republik Indonesia Nomor 6 Tahun 2020 tentang Perubahan Atas Peraturan Menteri Desa, Pembangunan Daerah Tertinggal; dan Transmigrasi Nomor 11 Tahun 2019 Tentang Prioritas Penggunaan Dana Desa Tahun 2020). Pada tahun 2018, pagu dana desa seluruh Indonesia sebesar $60 \mathrm{~T}$ dengan presentase transfer RKUD ke RKDesa sebesar 99,56\% dan pada tahun 2019 mengalami kenaikan menjadi $70 \mathrm{~T}$ dengan presentase transfer RKUD ke RKDesa sebesar 99,54\% (Kemendesa, 2017). Adapun data penyaluran alokasi dana Desa Sengkubang pada tahun 2018 dan 2019 dapat dilihat pada tabel 1.

Tabel 1. Penyaluran Alokasi Dana Desa Sengkubang Tahun 2018 (Pusat Data Desa Indonesia Dashboard (kemendesa.go.id).

\begin{tabular}{|c|c|c|}
\hline No. & Penyaluran & Pagu (Rp) \\
\hline 1. & Tahap 1 & 158.281 .000 \\
\hline 2. & Tahap 2 & 316.562 .000 \\
\hline 3. & Tahap 3 & 316.562 .000 \\
\hline \multicolumn{2}{|c|}{ Total } & $\mathbf{7 9 1 . 4 0 5 . 0 0 0}$ \\
\hline
\end{tabular}

Berdasarkan Tabel 1, pada tahun 2018 Desa Sengkubang menerima dana desa dengan total pagu Rp.791.405.000,00 dengan mekanisme penyaluran 3 (tiga) tahapan. Tahapan pertama Rp.158.281.000,00, tahapan kedua Rp.316.562.000,00 dan tahapan ketiga sebesar Rp.316.562.000,00. Penyerapan Dana Desa pada tahun 2018 juga melalui tiga tahapan yang pertama Rp.203.106.227,00, tahapan kedua Rp.217.163.828,00, dan ketiga Rp.419.860.785,00 dan memiliki data rencana kegiatan seperti yang terlihat pada tabel 2 .

Berdasarkan tabel 2, besaran pagu dana desa yang diberikan pada tahun 2018 sebesar Rp.791.405.000,00 dan dialokasikan pada 13 kegiatan. Dari data uraian kegiatan alokasi dana pagu terbesar berada pada Kegiatan Pembangunan, dan Pemeliharaan Selokan sebasar Rp.451.310.115,00 dan alokasi dana terendah pada kegiatan Kegiatan Pelatihan Lembaga Sosial Masyarakat (RT/RW) dan lain-lain sebesar Rp. 9.548.000,00 (Kementrian Desa, 2020). Sedangkan data penyaluran alokasi dana Desa Sengkubang tahun 2019 dapat dilihat pada tabel 3.

Bedasarkan tabel 3, pada tahun 2019 Desa Sekubang menerima dana desa dengan total pagu Rp.1.056.613.000,00 dengan mekanisme penyaluran 3 (tiga) tahapan. Tahapan pertama Rp.211.322.600,00, tahapan kedua Rp.422.645.200,00 dan tahapan ketiga sebesar Rp.422.645.200,00 (PDDI Kemendesa.go.id, 2019). 
Tabel 2. Rencana Penggunaan Dana Desa Sengkubang Tahun 2018 (Sistem

Informasi Pembangunan Desa (kemendesa.go.id)

\begin{tabular}{|c|c|c|c|}
\hline No & Tahun & Uraian kegiatan & Anggaran (Rp) \\
\hline 1 & 2018 & $\begin{array}{lll}\text { Kegiatan } & \text { Pembangunan, } & \text { dan } \\
\text { Pemeliharaan Selokan } & \end{array}$ & 451.310 .115 \\
\hline 2 & 2018 & Kegiatan Pembangunan Pasar Desa & 16.088 .375 \\
\hline 3 & 2018 & Kegiatan Pembangunan Jembatan & 26.309 .638 \\
\hline 4 & 2018 & 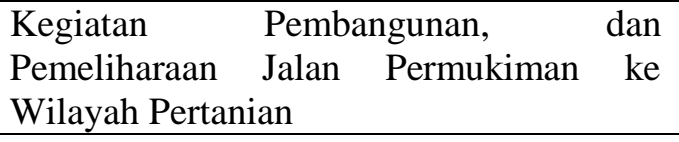 & 131.586 .290 \\
\hline 5 & 2018 & $\begin{array}{l}\text { Kegiatan Pengadaan, Pembangunan, dan } \\
\text { Pemeliharaan Pembangkit Listrik Tenaga } \\
\text { Diesel }\end{array}$ & 26.406 .000 \\
\hline 6 & 2018 & $\begin{array}{l}\text { Kegiatan Pembangunan, Pengembangan } \\
\text { dan Pemeliharaan MCK }\end{array}$ & 20.070 .745 \\
\hline 7 & 2018 & $\begin{array}{l}\text { Kegiatan Pembangunan, Pengembangan } \\
\text { Wahana Permainan PAUD }\end{array}$ & 19.364 .255 \\
\hline 8 & 2018 & $\begin{array}{l}\text { Kegiatan Pembangunan, Pengembangan } \\
\text { dan Pemeliharaan Taman Belajar } \\
\text { Keagamaan }\end{array}$ & 41.048 .230 \\
\hline 9 & 2018 & $\begin{array}{l}\text { Kegiatan Pengadaan, Pembangunan dan } \\
\text { Pemeliharaan Sarana Prasarana Produksi } \\
\text { Pertanian Lainnya }\end{array}$ & 14.715 .000 \\
\hline 10 & 2018 & $\begin{array}{l}\text { Kegiatan Pengadaan, Pengembangan, dan } \\
\text { Pemeliharaan Pelestarian Lingkungan } \\
\text { Hidup }\end{array}$ & 11.010 .000 \\
\hline 11 & 2018 & $\begin{array}{l}\text { Kegiatan Pembinaan Lembaga } \\
\text { Keagamaan }\end{array}$ & 11.928 .202 \\
\hline 12 & 2018 & $\begin{array}{lcc}\text { Kegiatan Pelatihan Lembaga } & \text { Sosial } \\
\text { Masyarakat (RT/RW) dll } & \\
\end{array}$ & 9.548 .000 \\
\hline 13 & 2018 & $\begin{array}{l}\text { Kegiatan Bantuan Pemberdayaan Bidang } \\
\text { Olahraga }\end{array}$ & 12.020 .150 \\
\hline
\end{tabular}

Dari data uraian kegiatan alokasi dana pagu terbesar berada pada kegiatan Pemeliharaan Prasarana Jalan Desa (Gorong-gorong, Selokan, Parit, Drainase dan lain-lain) sebesar Rp.413.614.800,00 dan alokasi dana terendah pada kegiatan Penyelenggaran PAUD/TK/TPA/TKA/TPQ/Madrasah Non Formal Milik Desa (Honor, Pakaian dan lain-lain) sebesar Rp.27.077.500,00 (Kementrian Desa, 2020). 
Tabel 3. Penyaluran Alokasi Dana Desa Sengkubang Tahun 2019 (Pusat Data Desa Indonesia Dashboard (kemendesa.go.id)

\begin{tabular}{|c|c|c|}
\hline No. & Penyaluran & Pagu (Rp) \\
\hline 1 & Tahap 1 & 211.322 .600 \\
\hline 2 & Tahap 2 & 422.645 .200 \\
\hline 3 & Tahap 3 & 422.645 .200 \\
\hline & Total & 1.056 .613 .000 \\
\hline
\end{tabular}

Kegiatan-kegiatan yang dibiayai dana desa harus sesuai dengan apa yang dimandatkan Undang-Undang Desa yakni bertujuan untuk pembangunan dan pemberdayaan masyarakat Desa.

Tabel 4. Rencana Penggunaan Dana Desa Sengkubang Tahun 2019 (Sistem Informasi Pembangunan Desa (kemendesa.go.id).

\begin{tabular}{|c|c|l|r|}
\hline No & Tahun & \multicolumn{1}{|c|}{ Uraian kegiatan } & Anggaran (Rp) \\
\hline 1 & 2019 & $\begin{array}{l}\text { Penyelenggaran } \\
\text { PAUD/TK/TPA/TKA/TPQ/Madrasah } \\
\text { NonFormal Milik Desa (Honor, Pakaian dll) }\end{array}$ & 27.077 .500 \\
\hline 2 & 2019 & $\begin{array}{l}\text { Pemeliharaan Jalan Usaha Tani } \\
\text { Pemeliharaan Prasarana Jalan Desa (Gorong- } \\
\text { gorong/Selokan/Parit/Drainase dll) }\end{array}$ & 105.621 .975 \\
\hline 3 & 2019 & 413.614 .800 \\
\hline 4 & 2019 & $\begin{array}{l}\text { Pembangunan/Rehabilitasi/Peningkatan } \\
\text { Pemakaman Milik Desa/Situs Bersejarah }\end{array}$ & 28.040 .125 \\
\hline 5 & 2019 & $\begin{array}{l}\text { Pemeliharaan Sumber Air Bersih Milik Desa } \\
\text { (Mata Air, Penampung Air, Sumur Bor dll) }\end{array}$ & 44.100 .000 \\
\hline 6 & 2019 & $\begin{array}{l}\text { Pembangunan/Rehabilitasi/Peningkatan Sistem } \\
\text { Pembuangan Air Limbah **) }\end{array}$ & 263.372 .100 \\
\hline 7 & 2019 & $\begin{array}{l}\text { Peningkatan Produksi Tanaman Pangan (alat } \\
\text { produksi/pengelolaan/penggilingan) }\end{array}$ & 93.678 .000 \\
\hline 8 & 2019 & $\begin{array}{l}\text { Pelatihan dan Penyuluhan Pemberdayaan } \\
\text { Perempuan }\end{array}$ & 81.108 .500 \\
\hline \multicolumn{2}{|c|}{ Total } \\
\hline
\end{tabular}

Menurut (Peraturan Menteri Desa, Pembangunan Daerah Tertinggal, dan Transmigrasi Republik Indonesia Nomor 6 Tahun 2020 tentang Perubahan Atas Peraturan Menteri Desa, Pembangunan Daerah Tertinggal; dan Transmigrasi Nomor 11 Tahun 2019 Tentang Prioritas Penggunaan Dana Desa Tahun 2020) menyebutkan pada Daftar Kegiatan Prioritas Bidang Pembangunan Desa sebagai berikut: (1) Pengadaan, pembangunan dan pemeliharaan sarana prasarana desa; (2) Peningkatan kualitas dan akses terhadap pelayanan sosial dasar; (3) Pengadaan, pembangunan, pengembangan dan pemeliharaan sarana prasana usaha ekonomi desa; (4) 
Pengadaan, pembangunan, pengembangan dan pemeliharaan sarana prasarana untuk pelestarian lingkungan hidup; dan (5) Pengadaan, pembangunan dan pemeliharaan sarana prasarana untuk penanggulangan bencana alam, non alam atau kejadian luar biasa lainnya.

Berdasarkan Tabel 4, besaran pagu dana desa yang diberikan pada tahun 2019 sebesar Rp.1.056.613.000,00 dan dialokasikan pada 8 kegiatan. Pagu dana desa akan dikurangi jika dalam hal terdapat Selisih Lebih Pembiayaan Anggaran (SiLPA) yang tidak wajar. SiLPA yang tidak wajar tersebut terjadi jika penggunaan dana desa tidak sesuai dengan prioritas dan uang disimpan dalam bentuk deposito lebih dari dua bulan. Pagu dana desa yang diperoleh Desa Sengkubang dari tahun 2018 s.d. 2020 selalu meningkat, hal tersebut dapat diartikan bahwa kegiatankegiatan yang direncanakan dan bersumber dari dana desa telah sesuai dengan prioritas kegiatan menurut Undang-Undang.

Tabel 5. Pagu Dana Desa Tahun 2018 s.d. 2020 (Sistem Informasi Pembangunan Desa (kemendesa.go.id).

\begin{tabular}{|l|c|c|c|}
\hline Tahun & 2018 & 2019 & 2020 \\
\hline Pagu (Rp) & 791.405 .000 & 1.056 .613 .000 & 1.123 .945 .000 \\
\hline Realisasi (Rp) & 786.118 .884 & 935.285 .500 & 1.053 .458 .350 \\
\hline Sisa (Rp) & 5.286 .116 & 121.327 .500 & 70.486 .650 \\
\hline Persentase (\%) & $99 \%$ & $89 \%$ & $93 \%$ \\
\hline
\end{tabular}

$$
\begin{aligned}
\text { Presentasi Realisasi (2018) } & =\frac{R p 786.118 .884}{R p 791.405 .000} \times 100 \% \\
& =99 \%
\end{aligned}
$$$$
\text { Presentasi Realisasi (2019) }=\frac{935.285 .500}{1.056 .613 .000} \times 100 \%
$$$$
=89 \%
$$

$$
\begin{aligned}
\text { Presentasi Realisasi }(2020) & =\frac{1.053 .458 .350}{1.123 .945 .000} \times 100 \% \\
& =93 \%
\end{aligned}
$$

Berdasarkan data pada tabel 5, efektivitas penggunaan Dana Desa tahun 2018 sebesar 99\%, tahun 2019 sebesar 89\%, dan pada tahun 2020 sebesar 93\%. Berdasarkan perhitungan persentasi realisasi, Dana Desa Sengkubang di nilai efektif sesuai dengan Keputusan Menteri Dalam Negeri No. 690.900.327 tahun 2016 tentang kriteria penilaian dan kinerja keuangan. 


\section{Pembangunan Desa Sengkubang}

Pembangunan desa menurut ( Pasal 78 Ayat (1) Undang-Undang Nomor 6 Tahun 2014 tentang Desa) bertujuan meningkatkan kesejahteraan masyarakat desa dan kualitas hidup manusia serta penanggulanggan kemiskinan melalui pemenuhan kebutuhan dasar pembangunan sarana dan prasarana desa, pembangunan potensi ekonomi lokal, serta pemanfaatan sumber daya alam dan lingkungan secara berkelanjutan. Pembangunan desa dilaksanakan oleh pemerintah desa dan masyarakat desa dengan semangat gotong royong serta memanfaatkan kearifan lokal dan sumber daya alam desa. Menurut (Undang-Undang Nomor 6 Tahun 2014 Tentang Desa) bahwa pembangunan desa meliputi tahap perencanaan, pelaksanaan, dan pengawasan, dan pada Pasal 79 mengenai Perencanaan Pembangunan Desa dijelaskan bahwa:

(1) Pemerintah Desa menyusun perencanaan pembangunan desa sesuai dengan kewenangannya dengan mengacu pada perencanaan pembangunan kabupaten

(2) Perencanaan pembangunan desa sebagaimana maksud ayat (1) disusun secara berjangka meliputi:

a. Rencana Pembangunan Jangka Menegah Desa untuk jangka waktu 6 (enam) tahun; dan

b. Rencana Pembangunan Jangka Menegah Desa Rencana Kerja Pemerintah Desa sebagaimana dimaksud pada ayat (2) ditetapkan dengan Peraturan Desa.

(3) Rencana Pembangunan Jangka Menengah Desa dan Rencana Kerja Pemerintah Desa sebagaimana dimaksud pada ayat (2) ditetapkan dengan Peraturan Desa.

(4) Peraturan Desa tentang Rencana Pembangunan Jangka Menengah Desa dan Rencana Kerja Pemerintah Desa merupakan satu-satunya dokumen perencanaan di Desa.

(5) Rencana Pembangunan Jangka Menengah Desa dan Rencana Kerja Pemerintah Desa merupakan pedoman dalam penyusunan Anggaran Pendapatan dan Belanja Desa yang diatur dalam Peraturan Pemerintah.

(6) Program Pemerintah dan/atau Pemerintah Daerah yang berskala lokal desa dikoordinasikan atau didelegasikan pelaksanaannya kepada desa.

(7) Perencanaan Pembangunan Desa sebagaimana dimaksud ayat (1) merupakan salah satu sumber masukan dalam perencanaan pembangunan kabupaten.

Berdasarkan Pusat Data Desa Indonesia menunjukan bahwa pada Tahun 2018 nilai IDM 0.623, sedangkan pada tahun 2019 nilai IDM 0.823 dengan rincian perhitungan sebagai berikut:

$$
\begin{gathered}
I D M=\frac{0.92+0.6833+0.8667}{3} \\
=0.823
\end{gathered}
$$


Bedasarkan Indeks Desa Membangun (IDM), klasifikasi desa mandiri nilai lebih dari 0.815 dapat diklasifikasikan menjadi desa dengan kategori mandiri. Berdasarkan IDM dan dikaitkan dengan data pada tabel 6 menunjukan pada tahun 2019 Desa Sengkubang memiliki nilai IDM sebesar 0.823. Maka, Desa Sengkubang dapat digolongkan sebagai kategori desa mandiri. Pada tahun 2020, nilai IDM Desa Sengkubang mengalami kenaikan nilai IDM sebanyak 6,93\% menjadi 0.8846 berstatus mandiri dan pada peringkat IDM Tahun 2020 menempati posisi 352 (Kementerian Desa, 2020).

Tabel 6. Indeks Desa Mandiri Desa Sengkubang Tahun 2019 (Pusat Data Desa Indonesia Dashboard (kemendesa.go.id).

\begin{tabular}{|l|c|c|}
\hline \multicolumn{1}{|c|}{ Jenis Indeks } & Persentase & $\begin{array}{c}\text { Nilai } \\
\text { Indeks Desa Mandiri } \\
\text { (IDM) }\end{array}$ \\
\hline $\begin{array}{l}\text { Indeks Ketahanan Ekologi } \\
\text { /Lingkungan (IKL) }\end{array}$ & $35.1 \%$ & 0.8667 \\
\hline Indeks Ketahanan Ekonomi (IKE) & $27.7 \%$ & 0.6833 \\
\hline Indeks Ketahanan Sosial (IKS) & $37.2 \%$ & 0.92 \\
\hline \multicolumn{2}{|c|}{ Nilai IDM } & $\mathbf{0 . 8 2 3}$ \\
\hline
\end{tabular}

\section{Implementasi Penggunaan Dana Desa}

Implementasi dana desa berupa hasil data wawancara yang dilakukan peneliti di Desa Sengkubang, Kecamatan Mempawah Hilir Provinsi Kalimantan Barat dengan menggunakan teori Edwards melalui 4 (empat) dimensi, yaitu komunikasi, sumberdaya, disposisi dan struktur birokrasi kepada aparatur desa. Adapun hasil wawancara sebagai berikut:

\section{a. Aparatur Desa Sengkubang}

1) Komunikasi

Komunikasi di Desa Sengkubang Kecamatan Mempawah Hilir Provinsi Kalimantan Barat dengan cara mensiosialisasikan kepada masyarakat desa terkait penggunaan dana desa diawali Musyawarah Dusun (MUSDUS) yang mengumpulan aspirasi masyarakat melalui kepala dusun dan dilanjutkan dengan pembuatan Rancangan Kegiatan Pemerintah (RKP) terkait kebutuhan masyarakat. Selanjutnya Desa Sengkubang melaksanakan Musyawarah Desa (MUSDES) yang melibatkan tokoh agama, tokoh masyarakat, dan prangkat desa serta Dewan Perwakilan Desa (DPD) yang membahas tentang rancangan kegiatan desa mencakup pemberdayaan, pembinaan dan pembangunan. Dalam proses sosialisasi tidak terdapat hambatan-hambatan dalam penyampaian informasi kepada masyarakat desa. Komunikasi dengan pihak internal di lingkup Kantor Desa Sengkubang antara aparatur menjalankan tugas dan fungsi sesuai dengan jabatan. Komunikasi dengan pihak-pihak eksternal hubungan dengan pemerintah Kabupaten 
Mempawah saling berkomunikasi dalam pembinaan dan pendampingan penggunaan dana desa.

2) Sumberdaya

Sumberdaya terkait jumlah aparatur di Desa Sengkubang sebanyak 13 anggota yang terdiri dari 1 orang Kepala Desa, 1 orang Sekretaris Desa, 1 orang Kasi Pemerintahan, 1 orang Kasi Kesejahteraan, 1 orang Kasih Pelayanan, 1 orang Kaur Umum, 1 orang Kaur Keuangan, 1 orang Kadus Bugis, 1 orang Kadus Suka Damai, 1 orang Kadus Simpang Tiga, 1 orang Kadus Parit Senin dan 2 orang Operator Desa. Kemampuan Sumber Daya Aparatur (SDA) di Desa Sengkubang cukup profesional namun masih ada permasalahan di dusun yang terkendala dari usia kepala dusun yang mengalami permasalahan terkait penggunaan teknologi, tetapi tidak menghambat kinerja menginggat tugas utama kepala dusun untuk menampung aspirasi dari masyarakat desa. Sumber Daya Aparatur (SDA) mendapatkan pelatihan peningkatan kapasitas Kepala Desa dan Perangkat Desa yang penganggarannya berasal dari APBD dan APBdes. Sarana dan prasarana di Desa Sengkubang masih kurang dari pembanggunan, pembinaan dan pemberdayaan. Pemanfaatan dana desa cukup baik dan disalurkan pada pembanggunan, pembinaan dan pemberdayaan. Dana desa dinilai masih belum tercukupi karena masih ada program desa yang masih memerlukan suntikan dana terkait program pada pembanggunan, pembinaan dan terutama pemberdayaan karena apabila masyarakat diberikan ilmu dan terpedaya dengan baik maka akan dapat melakukan tugas - tugas desa lainnya.

3) Disposisi

Sikap aparatur dalam penggunaan dana desa bersifat responsif. Pemerintah daerah sangat mendukung kegiatan dana desa karena sesuai dengan visi dan misi Presiden Jokowi yang mengutamakan pembangunan dari desa sehingga dapat mendorong percepatan pembangunan nasional. Komitmen penggunaan dana desa sesuai dengan perencanaan rancangan kinerja desa. Pengawasan dan pengendalian dana desa cukup baik dari pihak pengawas inspektorat daerah terkait pengawasan dan pembinaan maupun Dinas Sosial di bidang Pemerintah Desa Kabupaten Mempawah. Hambatan dalam pengelolaan dana desa bersifat internal, terkait Sumber Daya Manusia (SDM) desa masih terlibat pro dan kontra dalam program yang ditetapkan seperti pembangunan jalan pertanian sedangkan program desa mengutamakan hasil dari pertanian.

4) Struktur Organisasi

Struktur Organisasi sudah berjalan dengan tugas dan fungsi sesuai dengan jabatan, namun posisi Kaur Perencanaan di Desa Sengkubang masih belum ada yang menduduki sehingga adanya rangkap tugas yang dilakukan oleh Kaur Keuangan. Pembagian kewenangan dan tanggung jawab sesuai dengan tugas dan fungsi masing - masing jabatan. 
Manfaat dana desa menjadikan desa menjadi lebih mandiri, dapat melakukan kewenangannya sesuai dengan karakteristik dan potensi dari masyarakat Desa Sengkubang. Cara pengambilan keputusan terkait dana desa melalui MUSdes yang libatkan tokoh agama, tokoh masyarakat, Badan Pengawas Desa (BPD), perangkat desa, komponen desa (RT, RW, RPM, PKK, FKPN).

\section{b. Masyarakat Desa Sengkubang}

1) Komunikasi

Komunikasi antara Aparatur Desa dengan Masyarakat Desa terinformasikan dengan lancar. Komunikasi diinformasikan melalui papan penggumuman yang berisikan tentang agenda kegiatan sehingga masyarakat dapat mengetahui dan ikut serta dalam pelaksanaan program kegiatan yang dilakukan.

2) Sumberdaya

Dana desa dinilai mencukupi dalam mendorong tercapainya desa mandiri. Dana desa dirasakan cukup karena apa yang diajukan oleh masyarakat terpenuhi.

3) Disposisi

Pemerintah Desa dirasakan mendukung kegiatan desa karena adanya dukungan moril maupun materil berupa anggaran dalam pelaksanaan kegiatan masyarakat.

4) Struktur Birokrasi

Manfaat yang dirasakan oleh masyarakat terhadap dana desa dapat dirasakan dari peningkatan pembangunan. Pembangunan yang dirasakan seperti pembangunan jalan di desa yang semakin baik. Masyarakat sendiri ikut terlibat secara langsung dalam pelaksanaan kegiatan dana desa berupa kegiatan gotong royong dalam pelaksanaan program pembangunan jalan di Desa Sengkubang.

Dari uraian diatas dapat disimpulkan hasil wawancara terhadap aparatur desa terkait implementasi dana desa tehadap pembangunan di Desa Sengkubang, Kecamatan Mempawah Hilir Provinsi Kalimantan Barat bahwa komunikasi telah berjalan dengan baik dengan melibatkan tokoh agama, tokoh masyarakat desa serta perangkat desa dalam MUSdes terkait pembahasan Rancangan Program Desa (RPD) yang sesuai dengan kebutuhan, karakteristik serta potensi yang ada di desa. Sumber Daya Aparatur (SDA) telah tersusun secara struktural namun didalam menjalankan tugas dan fungsi masih ada tumpang tindih terhadap tugas yang disebabkan Kaur Perencanaan yang kosong sehingga tugas tersebut dibebankan kepada Kaur Keuangan. Disposisi di Desa Sengkubang terkait dengan sifat Aparatur Desa yang responsif dalam menjalankan tugas dan fungsi serta hambatan teknis berupa kemampuan dari Kepala Dusun yang masih belum menguasai teknologi namun dapat mengumpulkan dan menyampaikan aspirasi dari masyarakat desa kepada Aparatur Desa. Namun dalam keputusan yang diambil Aparatur Desa lebih mengedepankan pemberdayaan terhadap masyarakat dibandingkan dengan 
pembinaan dan pembangunan sehingga menimbulkan pro dan kontra dikalangan masyarakat desa. Struktur organisasi telah berjalan dengan baik dimana aparatur mampu menjalankan tugas dan fungsi dari masing-masing jabatan. Keputusan yang diambil terkait dana desa sudah dinilai tepat dimana disesuaikan dengan kebutuhan masyarakat Desa Sengkubang.

Sedangkan terkait hasil wawancara kepada masyarakat Desa Sengkubang terkait Implementasi Dana Desa Terhap Pembangunan di Desa Sengkubang Kecamatan Mempawah Hilir Provinsi Kalimantan Barat bahwa komunikasi antar masyarakat dengan aparatur desa berjalan dengan lancar. Informasi yang disampaikan dapat diperoleh oleh masyarakat desa dengan baik melalui papan informasi yang berisikan tentang agenda kegiatan desa. Dari informasi tersebut masyarakat dapat ikut serta dalam pelaksanaan kegiatan program desa. Sumber Daya Manusia (SDM) dinilai mencukupi untuk mendorong tercapainya desa mandiri. Masyarakat desa merasakan dukungan moril maupun materil dari aparatur desa dimana kegiatan ataupun program mendapatkan dukungan dana berupa dana desa. Secara umum, dana desa di Desa Sengkubang dinilai cukup baik oleh masyarakat karena banyaknya pembangunan jalan yang dirasakan masyarakat yang sangat mendukung aktivitas masyarakat setiap harinya.

\section{SIMPULAN}

Desa Sengkubang pada tahun 2018 mendapatkan alokasi dana desa sebesar Rp.791.405.000,00, sedangkan pada tahun 2019 Desa Sekubang menerima dana desa dengan total pagu Rp.1.056.613.000,00. Bedasarkan data realisasi dana Desa Sengkubang, efektivitas penggunaan dana desa pada tahun 2018 sebesar 99\%, tahun 2019 sebesar 89\%, dan pada tahun 2020 sebesar 93\%, penggunaan dana Desa Sengkubang dinilai efektif sesuai dengan Keputusan Menteri Dalam Negeri No. 690.900.327 tahun 2016 tentang kriteria penilaian dan kinerja keuangan.

Pembangun pada Desa Sengkubang berdasarkan Pusat Data Desa Indonesia menunjukan pada tahun 2018 nilai Indeks Desa Membangun (IDM) sebesar 0.623 dan pada tahun 2019 nilai IDM sebesar 0.823. IDM tersebut menunjukan bahwa Desa Sengkubang digolongkan sebagai katagori desa mandiri. Pada tahun 2020, IDM Desa Sengkubang mengalami kenaikan nilai sebanyak 6,93\% menjadi 0.8846 berstatus mandiri dan pada peringkat IDM tahun 2020 menempati posisi 352.

Implementasi Dana Desa Sengkubang dengan menggunakan teori implementasi Edwards dari keempat dimensi komunikasi, sumberdaya, disposisi dan struktur birokrasi secara umum sudah berjalan cukup baik namun secara teknis masih mengalami kendala seperti keterbatasan penggunaan teknologi di tingkat dusun, pro dan kontra terhadap program utama desa dan masih belum tercukupi dari segi anggaran.

\section{DAFTAR PUSTAKA}

Badan Pusat Statistik. (2016). Badan Pusat Statistik. Diambil dari Badan Pusat Statistik: https://www.bps.go.id/. 
Edwards, G. C. (1980). Implementing Public Policy. Washington DC: Congressional Quarterly Press.

Indiahono, D. (2009). Kebijakan Publik Berbasis Dynamic Policy Analysis. Gava Media.

Implementasi. (2016). Pada KBBI Daring. Diambil dari https://kbbi.web.id/implementasi.

Kementerian Desa, P. D. (2020). Indeks Desa Membangun. Diambil dari IDM : Indeks Desa Membangun Kementerian Desa, Pembangunan Daerah Tertinggal dan Transmigrasi: https://idm.kemendesa.go.id/status.

Kemendesa, S. P. (2017). Penyaluran Dana Desa tahun 2015-2019. Diambil dari from Sistem Informasi Pembangunan Desa: https://sipede.ppmd.kemendesa.go.id/

Kementrian Desa, P. d. (2020). Portal Kementrian Desa, PDT dan Transmigrasi. Diambil dari Website Kementrian Desa, PDT dan Transmigrasi: https://www.kemendesa.go.id/.

Listyaningsih. (2014). Administrasi Pembangunan : pendekatan konsep dan implementasi. Yogyakarta: Graha Ilmu.

PDDI Kemendesa.go.id. (2019). Data Pagu, Penyaluran dan Penyerapan Dana Desa 2019. Diambil dari Pusat Data Desa Indonesia: https://pddi.kemendesa.go.id/kemenkeu/realisasi_pagu.

Republik Indonesia. 2020. Peraturan Menteri Desa, Pembangunan Daerah Tertinggal, dan Transmigrasi Rublik Indonesia Nomor 6 Tahun 2020 tentang Perubahan Atas Peraturan Menteri Desa, Pembangunan Daerah Tertinggal, dan Transmigrasi Nomor 11 Tahun 2019 Tentang Prioritas Penggunaan Dana Desa Tahun 2020. Jakarta: Menteri Desa, Pembangunan Daerah Tertinggal, dan Transmigrasi Rublik Indonesia.

Republik Indonesia. 2014. Peraturan Pemerintah nomor 60 Tahun 2014 tentang Dana Desa Yang Bersumber Dari Anggaran Pendapatan dan Belanja Negara. Jakarta: Kementerian Sekretariat Negara Rublik Indonesia.

Republik Indonesia. 2014. Undang - undang Nomor 6 Tahun 2014 tentang Desa. Jakarta: Kementerian Sekretariat Negara Rublik Indonesia.

Republik Indonesia. 2016. Keputusan Menteri Dalam Negeri No. 690.900.327 tahun 2016 tentang kriteria penilaian dan kinerja keuangan. Jakarta: Kementerian Dalam Negara Rublik Indonesia. 
Siagian, S. P. (2010). Manajemen Sumber Daya Manusia. Bumi Aksara.

Taufik, M., \& dkk. (2019). Status IDM Indeks Desa Membangun Provinsi Kabupaten Kecamatan Tahun 2019. Jakarta: Direktorat Jenderal Pembangunan dan Pemberdayaan Masyarakat Desa Kementerian Desa, PDT dan Transmigrasi. 